\title{
Idea nowego jugoslawizmu
}

Do napisania niniejszego tekstu skłonił autorkę rozdział w książce Nebeska Jugoslavija. Interakcije političkih mitologija $i$ pop-kulture, napisany przez słoweńskiego kulturologa Mitję Velikonję i poświęcony idei nowego jugoslawizmu we współczesnej słoweńskiej muzyce. Jak powszechnie wiadomo, pojęcie jugoslawizmu dotyczyło działań na rzecz zjednoczenia Słowian południowych, przede wszystkim na płaszczyźnie kulturowej oraz politycznej w XIX w. Jak zauważa Lilla Moroz-Grzelak, współpraca ta okazała się fiaskiem, a jej jedynym, wcielanym w życie, elementem była umowa językowa z 1850 r. ${ }^{1}$ Maciej Czerwiński, analizując chorwackie i serbskie wizje dziejów, zauważa, iż pośród tamtejszych historyków dominuje negatywne spojrzenie na procesy integracyjne ${ }^{2}$.

Nowy jugoslawizm (novi jugoslavizam) nie jest, jakby się mogło wydawać, próbą współczesnej reaktywacji procesów unifikacyjnych. Velikonja definiuje go - wzorem Edwarda Saida czy Marii Todorovej - jako dyskurs na temat Jugosławii, zarówno w wymiarze wewnętrznym - na obszarze dawnej Socjalistycznej Federacyjnej Republiki Jugosławii (SFRJ) ${ }^{3}$,

${ }^{1}$ L. Moroz-Grzelak, Bracia Stowianie. Wizje wspólnoty a rzeczywistość, Warszawa 2011, s. 115.

${ }^{2}$ M. Czerwiński, Semiotyka dyskursu historycznego. Chorwackie i serbskie syntezy dziejów narodu, Kraków 2012, s. 250-255.

${ }^{3}$ Nazwa państwa jugosłowiańskiego od $1963 \mathrm{r}$. 
jak i zewnętrznym: Nowy jugoslawizm pojmuje jako kompleksowa, wielowarstwowa, schizofreniczna $i$ konfliktowa ideologię, która się rodzi zarówno $w$ środku ówczesnych granic, jak i poza nimi, i która mówi o Jugosławii ${ }^{4}$ Taka definicja sugeruje, że mamy do czynienia z chaotycznymi refleksjami, że brak im uporządkowania, a w dodatku nie brakuje wypowiedzi przeciwstawnych, wzajemnie wykluczających się. Innymi słowy, badacz ów, używając pojęcia nowy jugoslawizm, ma na myśli imaginarna Jugostawię, a więc obraz wspólnego państwa, funkcjonujący w wyobrażeniach zbiorowych. Velikonja dokonuje zresztą rozróżnienia na jugoslawizm negatywny i pozytywny, zastrzegając, że w każdym z postjugosłowiańskich społeczeństw te dwa dyskursy współistnieją obok siebie, że krytyczny stosunek względem dawnego państwa nakłada się na postawy nostalgiczne i postulaty zacieśniania regionalnej współpracy. Biorąc pod uwagę niedostatki ludzkiej pamięci i prawa inżynierii społecznej, podkreślić trzeba, że Jugosławia wyobrażona - zarówno postrzegana negatywnie, jak i pozytywnie - konstruowana jest bardzo swobodnie, w oparciu o selektywnie dobrane fakty i gotowe tezy.

Velikonja w swoim artykule zawęża rozważania do przykładów ze słoweńskiej muzyki, gdzie rozwija się pozytywny jugoslawizm, która to teza została poparta szerokim spektrum przykładów. Przykładowo badacz pisze, że nie słyszał, aby muzycy śpiewali o José Barroso, Helmucie Kohlu czy Javierze Solanie, ale przecież nierzadko w swoich utworach opiewaja byłą Jugosławię, jej przywódcę, jak i titowską partyzantkę ${ }^{5}$. Wydaje się więc zasadne wyjście poza przyjęte przez słoweńskiego kulturologa ramy i próba przyjrzenia się postrzeganiu

${ }^{4}$ M. Velikonja, Rock'n'Retro. Novi jugoslavizam u savremenoj slovenačkoj popularnoj muzici, [w:] V. Perica, M. Velikonja, Nebeska Jugoslavija. Interakcije političkih mitologija i pop-kulture, Beograd 2012, s. 84.

${ }^{5}$ Ibidem, s. 70. 
wspólnego państwa przez społeczeństwa postjugosłowiańskie na płaszczyźnie politycznej, społecznej, kulturowej, pytając się o współczesny stosunek względem nieistniejącego już państwa Słowian południowych.

Po rozpadzie SFRJ dominowało przekonanie, iż eksperyment ponadnarodowej federacji był błędem, choć oczywiście każda ze stron odmiennie tłumaczyła przyczyny niepowodzenia, zazwyczaj przerzucając winę na innych ${ }^{6}$. Chorwaci i Słoweńcy oskarżali Belgrad o serbską hegemonię, ciemiężenie Kościoła katolickiego, jak i bezprawne „narzucanie haraczu” - jak interpretowano fundusz na rzecz regionów słabiej rozwiniętych. W latach 80 . XX w., kiedy recesja przybierała coraz bardziej na sile, drastycznie spadała jakość życia, owa sytuację najłatwiej było tłumaczyć w bogatszych republikach okradaniem ich przez Belgrad ${ }^{7}$. Do dziśs słoweńscy historycy podkreślaja, że eksperyment jugosłowiański był wielkim rozczarowaniem, bowiem Republika Alpejska nie tylko utraciła suwerenność, ale również ponosiła niepotrzebne koszty ${ }^{8}$. Serbowie narzekali na separatyzmy innych nacji, wymierzone w integralność terytorialną ich ziem. Albańczycy, czując się poniżani i marginalizowani w państwie Słowian południowych, którego nazwa pomijała ich nację, domagali się niezależności. Boszniacy, choć zachowali wdzięczność wobec Josipa Broz-Tity za uznanie ich za odrębny naród, mieli za złe Serbom i Chorwatom dażenia do podziału ich terytorium, oparte na przekonaniu, że zislamizowani Słowianie to $\mathrm{w}$ istocie

${ }^{6}$ M. Czerwiński, Byta Jugostawia - topografia pamięci zbiorowej, „Herito. Dzedzictwo, kultura, współczesność" 2013, nr 13, s. 59-60.

${ }^{7}$ L.M. Nijakowski, Rozkosz zemsty. Socjologia historyczna mobilizacji ludobójczej, Warszawa 2013, s. 143-144.

${ }^{8}$ W. Höpken, Slowenien im ersten und zweiten Jugoslawien, [w:] Die Grundlagen der slowenischen Kultur, hrsg. von F. Bernik und R. Lauer, Berlin 2010, s. 85. 
członkowie ich nacji. Nadto Boszniacy narzekali, że w komunistycznym państwie większość lepszych stanowisk zajmowali Serbowie, a ich uznawano za ludzi mniej wykształconych. Dyrektorka pewnej sarajewskiej szkoły tak opisywała treści, występujące w jugosłowiańskich materiałach edukacyjnych: Wszędzie tak byto: Ojciec Dragana (imię serbskie) jest pilotem. Ojciec Seja (imię muzutmańskie) jest mechanikiem samochodowym ${ }^{9}$.

Macedończycy, choć początkowo nie posiadali programu wyjścia z federacji ani strategii osiagnięcia suwerenności, a ich ówcześni przywódcy byli zorientowani proserbsko ${ }^{10}$, zadecydowali w referendum w 1991 r. o niepodległości. Z kolei Czarnogórcy, choć w 1992 r. głosowali za pozostaniem w związku z Serbia, dość szybko zmienili zdanie. W 1996 r., kiedy ludzie powiązani z żoną Slobodana Miloševicia, Mirą Marković, próbowali przejąć kontrolę nad czarnogórską gospodarka, prezydent Milo Đukanović zaczął dystansować się wobec działań Belgradu i prowadzić własna, prozachodnia politykę. Konsekwencja tego było przyjęcie jako waluty marki niemieckiej (zastapionej w 2001 r. przez euro), a w końcu ogłoszenie przez Podgoricę niepodległości w $2006 \mathrm{r}$. Te fakty przypominamy, by pokazać, że Jugosławia przestała być potrzebna, że nastapił zmierzch idei wspólnego państwa. Tym samym nie dziwi negatywne postrzeganie SFRJ, ale zjawisko określone przez Velikonję mianem pozytywnego jugoslawizmu musi zastanawiać.

Łatwo zrozumieć nostalgię biedniejszych krajów, które $\mathrm{w}$ czasach jugosłowiańskich otrzymywały znacząca pomoc

${ }^{9}$ Cyt. za: B. Demick, W oblężeniu. Życie pod ostrzałem na sarajewskiej ulicy, przeł. A. Pustała-Lewicka, Wołowiec 2014, s. 102.

${ }^{10}$ M. Korzeniewska-Wiszniewska, Stanowisko serbskie wobec procesu tworzenia państwa macedońskiego w 1991 roku, [w:] Macedoński dyskurs niepodległościowy. Historia, kultura, literatura, język, media, red. I. Stawowy-Kawka, M. Kawka, Kraków 2011, s. 223, 225. 
ekonomiczną z budżetu federacji. Wojciech Śmieja tłumaczy w jednym ze swoich reportaży, iż Macedończycy tęsknią za epoka, która zrównywała wyschta górzysta kraine pasterzy $z$ nobliwa Stowenia, nieprzytomnie piękna Chorwacja czy skrojona na miare lokalnego mocarstwa Serbia ${ }^{11}$. O ile nietrudno przyjąc taką argumentację, to ciepłe wspomnienie o Jugosławii w północnej części dawnej federacji, a w szczególności w analizowanej przez Velikonję Słowenii, wymaga szerszego wyjaśnienia. Odwołać się tutaj trzeba do płaszczyzny psychologicznej, do wyobrażeń zbiorowych społeczeństw postjugosłowiańskich, które ciagle pamiętają o mocarstwowej przeszłości, kiedy ich państwu zdecydowanie bliżej było do świata Zachodu. Dziś nawet należące do Unii Europejskiej (UE) Słowenia i Chorwacja musza ciagle potwierdzać swoją europejskość. Pierwsza z wymienionych czuje się tym bardziej upokorzona wobec kojarzenia jej ze Słowacją (zdarzyło się to np. Georgowi W. Bushowi i Silvio Berlusconiemu) ${ }^{12}$. Słoweński filozof Rastko Močnik podkreśla, iż ciagłe piętnowanie postkomunistycznego Wschodu jako gorszej części Europy skutkuje imaginacyjnymi ucieczkami do przeszłości, gdzie przywracana jest człowiekowi godność, której pozbawia się go w dzisiejszej rzeczywistości ${ }^{13}$.

Nadto Jugosławia funkcjonuje w wyobrażeniach zbiorowych jako alternatywa dla ideologii nacjonalizmu ${ }^{14}$, a dla jednostek mających tragiczne wspomnienia związane

${ }^{11}$ W. Śmieja, Gorsze światy. Migawki z Europy Środkowo-Wschodniej, Warszawa 2012, s. 245.

${ }^{12}$ Slovenia is not Slovakia, http://www.slovak-republic.org/slovenia/ (dostęp 2 III 2014).

${ }^{13}$ B. Buden, Zona prelaska. O kraju postkomunizma, Beograd 2012, s. $72-73$.

${ }^{14}$ A. Synowiec, (Re)konstrukcje tożsamości. Wielogłos pamięci zbiorowych na przykładzie Republiki Bośni i Hercegowiny, [w:] Wielokulturowość: 
z rozpadem SFRJ, np. mieszkańców Bośni i Hercegowiny - nostalgia za dawnym państwem jest formą wyrażenia pragnienia pokojowej koegzystencji. Mając to na uwadze, łatwiej zrozumieć pozytywne oceny Jugosławii, tym bardziej, że od jej rozpadu minęło już ponad 20 lat, a taka perspektywa przyczynia się do idealizacji dawnych czasów. Nowa, niepewna rzeczywistość rodzi strachy przed nieznanym ${ }^{15}$, które wymagają sublimacji, czego najprostszą formą jest powołanie się na sprawdzoną przeszłość. Mechanizm ten analizował na przykładzie postkolonialnej Afryki Clifford Geertz, a wiele jego spostrzeżeń można z powodzeniem odnieść do Bałkanów. Geertz pisze m.in. o mrocznych nastrojach, rozmytym przywództwie, zawiedzionych nadziejach zbiorowych, rozczarowaniu polityka partyjna i postawa elit ${ }^{16}$. Nic więc dziwnego, iz rosnace przez lata rozczarowanie rodzi miłe wspomnienia o dawnym państwie.

Rozważania na temat pozytywnego jugoslawizmu należy zacząć od zwrócenia uwagi na zainteresowanie regionem wśród państw powstałych na gruzach federacji, które zrodziło się w miejsce charakterystycznego dla końca XX w. trendu dystansowania się od Bałkanów. Jak zauważa M. Todorova, ta część Europy nigdy w historii nie doświadczyła zgodnego współdziałania i choć nie brakowało intelektualistów, postulujących współpracę, wzajemne zrozumienie, zwykle do głosu dochodzili przywódcy manipulujacy masami przy pomocy sloganów odwołujących się do starych podziałów ${ }^{17}$. Tymczasem

konflikt czy koegzystencja, pod red. A. Śliz i M.S. Szczepańskiego, Warszawa 2011, s. 183.

${ }^{15}$ M. Kula, Kartki z socjologii historycznej, Warszawa 2014, s. 189.

${ }^{16}$ C. Geertz, Interpretacja kultur. Wybrane eseje, Kraków 2005, s. $269-272$.

${ }^{17}$ M. Todorova, Dizanje prošlosti u vazduh. Ogledi o Balkanu i Istočnoj Evropi, Beograd 2010, s. 83-84. 
od zakończenia wojen z lat 90. XX w. mówić można o współpracy regionalnej, poczattkowo inspirowanej zreszta przez $\mathrm{UE}^{18}$, która z biegiem lat ulega coraz większej intensyfikacji ${ }^{19}$. Aleksandar Petric podkreśla, że po raz pierwszy w historii kraje Bałkanów Zachodnich posiadaja wspólny cel strategiczny, jakim jest integracja europejska, którego realizacja wymaga wzajemnej kooperacji ${ }^{20}$.

Słoweńcy i Chorwaci zdaja się rozumieć, że szansą dla realnego zaistnienia małych państw na arenie Unii jest tzw. specjalizacja, a więc ograniczenie swojej aktywności do dziedziny, w której sprawdzają się najlepiej i dzięki temu moga zostać docenione przez Brukselę. Dla obu krajów jedyną taką sfera jest położenie geograficzne i doświadczenie wspólnej, jugosłowiańskiej przeszłości. Stąd też nie dziwią inicjatywy Lublany i Zagrzebia na rzecz integracji państw regionu z UE. W tym miejscu nadmienić trzeba, iż pomiędzy Zagrzebiem a Lublaną występowały napięcia $\mathrm{w}$ związku $\mathrm{z}$ kwestią o rozgraniczenia wód terytorialnych w Zatoce Pirańskiej. Doprowadziły one nawet do słoweńskiego weta $\mathrm{w}$ negocjacjach akcesyjnych Chorwacji do Unii. Emocje, podgrzewane po obu stronach przez

${ }^{18}$ Początkowo bałkańskie społeczeństwa spoglądały krytycznie na ideę integracji, mówiono o zakamuflowanym pomyśle powrotu do Jugosławii, zob. np. N. Whyte, Unia Europejska i Batkany Zachodnie, [w:] Rok 1989 - 20 lat później. Kraje postkomunistyczne a integracja europejska, [red. A. Ostolski, M. Kopka], Warszawa 2009, s. 109.

${ }^{19}$ D. Lopandic, Regional Cooperation in the Balkan Countries and the Process of their Integration with the European Union, [w:] India and Serbia, and Montenegro Re-engagement: Regional and Bilateral Dimensions, New Delhi 2005, s. 97-98; L. Benson, Jugostawia. Historia $w$ zarysie, tł. B. Gutowska-Nowak, Kraków 2011, s. 280.

${ }^{20}$ A. Petric, Srpska ekonomska situacija na raskršću, [w:] Srbija je važna. Unutrašnje reforme i europske integracije, ur. V. Petrič, G. Svilanović, K. Solioz, Beograd 2009, s. 216. 
nacjonalistów ${ }^{21}$, udało się szybko opanować, spór przekazano pod arbitraż międzynarodowy, a prezydent Ivo Josipović wybrał się w swoją pierwszą zagraniczną podróż do Słowenii ${ }^{22}$.

Wizję bycia pomostem posiada również Serbia, pretendująca do roli pośrednika pomiędzy Rosją a UE ${ }^{23}$. Belgrad nie tylko nie poparł nałożonych na Moskwę sankcji, ale, co więcej, w serbskich mediach pojawiły się analizy, negujace sama ideę tego rodzaju karania. Zwolennicy koncepcji budowania pomostu pomiędzy Unią a Rosją zauważaja, iż podobna funkcję pełniło kiedyś średniowieczne państwo serbskie, do której Belgrad po długich latach może z powodzeniem powrócić. Podkreślano istotną rolę planowanego gazociagu południowego (South Stream), który miał przebiegać przez terytorium Serbii ${ }^{24}$. Jego uruchomienie miało znacząco wzmocnić pozycję kraju na arenie międzynarodowej

${ }^{21}$ Przykładowo lider populistycznej Słoweńskiej Partii Narodowej (Slovenska nacionalna stranka, SNS) Zmago Jelinčič Plemeniti wzywał Serbów, Czarnogórców i Bośniaków do poparcia walki przeciwko Chorwatom, w Chorwacji zaś pewien weteran wojenny planował próbę zamachu na Boruta Pahora. Zob. np. W. Korczyński, Nie gasna emocje wokót porozumienia chorwacko-stoweńskiego, http://www.mojeopinie.pl/nie_gasna_emocje_wokol_porozumienia_chorwackoslowenskiego,3,1259279317 (dostęp 2 III 2014); An Assassination Attempt (or so they would have you believe), http://www.pengovsky.com/2009/07/14/an-assassination-attempt-or-so-they-would-have-you-believe/ (dostęp 2 III 2014).

${ }^{22}$ W.C. Thompson, Nordic, Central, and Southeastern Europe 2013, Lanham 2013, s. 426.

${ }^{23}$ R. Vlahutin, Europska Unija, Zapadni Balkan i Srbija: mogu li se stvari ipak raditi bolje?, [w:] Srbija je važna..., s. 66.

${ }^{24} \mathrm{~W}$ grudniu 2014 r. przywódca Rosji, Władimir Putin, ogłosił definitywny upadek projektu, co bardzo rozczarowało Serbów. Premier Aleksandar Vučić nie kryjąc żalu stwierdził, iż jego kraj płaci cenę za konflikt wielkich, Srbija plaća cenu velikih, 2 XII 2014, http://www.studiob.rs/info/vest. php?id=111358 (dostęp 9 I 2015). 
i de facto uczynić z niego łącznik pomiędzy Wschodem a Zachodem ${ }^{25}$. Nadto zauważyć trzeba, iż Serbowie pamiętają czasy, kiedy to oni dominowali w świecie Słowian południowych, a przekonanie o byciu potęga zwykle trwale wpisuje się $\mathrm{w}$ wyobrażenia zbiorowe. Nie moga więc dziwić aspiracje do odgrywania roli regionalnego lidera ${ }^{26}$. Takim przeświadczeniom towarzyszą poszukiwania argumentów natury geograficznej, czy też geopolitycznej. Podkreśla się istotę położenia kraju na skrzyżowaniu szlaków komunikacyjnych, a także wyjątkowe usytuowanie Belgradu u zbiegu dwóch rzek - Sawy i Dunaju, co ma kluczowe znaczenie dla rozwoju transportu ${ }^{27}$. Zdawali się to dostrzegać eksperci brytyjskiego dziennika „Financial Times”, określając w 2006 r. serbską stolicę mianem miasta przyszłości Europy Południowo-Wschodniejej.

Nadto Serbowie staraja się przewodzić państwom regionu w procesie integracji europejskiej. I tak np. w $2009 \mathrm{r}$. serbski minister spraw zagranicznych, Vuk Jeremić, zadeklarował, że jego kraj jest gotów pomóc Bośni i Hercegowinie w integracji z UE. Utworzony w 2004 r. Urząd ds. Integracji Europejskiej (Kancelarija za evropske integracije), negocjując Proces Stabilizacji i Stowarzyszenia, podzielił się

${ }^{25}$ J. Kovacic, Russia, Serbia and South Stream, „Transconflict”, 27 XI 2013, http://www.transconflict.com/2013/11/russia-serbia-south-stream-271/ (dostęp 3 III 2013).

${ }^{26}$ Trzeba w tym miejscu podkreślić reorientację retoryki władz serbskich, bowiem jednym z fundamentów epoki rządów Miloševicia stał się misjonizm, tyle że w romantycznym wymiarze. Nowy, proeuropejski kierunek polityki państwa musiał przełożyć się na przewartościowania w dziedzinie sfery symbolicznej. Slogany o potrzebie prowadzenia misji zostały więc dostosowane do realiów XXI w.

${ }^{27}$ A. Petric, op. cit., s. 212.

${ }^{28}$ Beograd - Grad budućnosti južne Evrope, http://www.beograd.rs/ cms/view.php?id=1223836 (dostęp 2 V 2014). 
doświadczeniami z kolegami z Sarajewa i Podgoricy ${ }^{29}$. Kiedy w styczniu 2009 r., na fali rosyjsko-ukraińskiego konfliktu gazowego, niedobór tegoż surowca zaczął trapić Bałkany, a w szczególności Bośnię i Hercegowinę, Belgrad przekazał Sarajewu część własnych rezerw ${ }^{30}$. Zdaniem Erica Gordy'ego, nie był to tylko gest przyjacielski, ale wyraz solidarności, wynikający z przekonania, iż cały region boryka się z podobnymi problemami i jedyna droga ich pokonania jest wzajemna pomoc i współpraca ${ }^{31}$.

Boszniacy pragna natomiast odgrywać rolę pośrednika pomiędzy światem muzułmańskim a Zachodem. Popularne twierdzenie, iż południowo-wschodnia część Starego Kontynentu to kolebka jego kultury i cywilizacji ${ }^{32}$, bywa wykorzystywane przy argumentacjach na rzecz integracji europejskiej, w której to Boszniacy mogliby obalić negatywne stereotypy na temat islamu, a także pomóc mentalnie przygotować społeczeństwa UE na włączenie doń Turcji. Dodajmy, iż podobne przekonanie żywią również kosowscy Albańczycy, czego wyrazem sa chociażby kampanie reklamowe: Kosovo between East and West albo Kosovo the Young Europeans. To ostatnie hasło odnosi się nie tylko do faktu, iż państwo to jest najmłodsze w Europie, ale również wskazuje na niską średnią wieku społeczeństwa, którego 65\% nie ma skończonego 30. roku życia ${ }^{33}$.

${ }^{29}$ T. Miščević, Administratiuni kapacitet Srbije: podsticanje europske integracije, [w:] Srbija je važna..., s. 104.

${ }^{30}$ Srbija isporučila gas Sarajevu, http://www.b92.net/biz/vesti/region. php?yyyy=2009\&mm=01\&dd=10\&nav_id=338624 (dostęp 28 IV 2014).

${ }^{31}$ E. Gordi, Suočacanje s prošlošću u Srbiji: prepreke i prilike, [w:] Srbija je važna..., s. 153-154.

${ }^{32}$ A. Velić, Bošnjaci i Evropa. Bošnjačko razumijevanje Evrope i zapadnoevropske kulture u periodu austrougarske uprave nad Bosnom i Hercegovinom 1878-1918, Sarajevo 2013, s. 25-26.

${ }^{33}$ M. Podstawski, Polska w Europie Środkowej, część I, http://www.rog. com.pl/demografiacz1.htm (dostęp 12 III 2014). 
Taki przekaz sugeruje, iż walorem Kosowa jest młodość, którą to wartość wniesie ono do starzejącej się Europy.

Zauważyć również trzeba, iż slogany o potrzebie prowadzenia misji rytualizuje przeważająca większość wspólnot. Przykładowo - silne przekonanie o dziejowym posłannictwie stało się udziałem Amerykanów ${ }^{34}$. Z kolei rosyjska Cerkiew prawosławna widzi dla siebie rolę mediatora pomiędzy Watykanem a światem islamu ${ }^{35}$. Takie treści łatwo trafiają do mas, bowiem człowiek świadomy niechybnego końca egzystencji za wszelką cenę pragnie nadać sens swojemu istnieniu. Robert Schuman pisał: Naród ma do spetnienia misje nie tylko wobec samego siebie, ale także i $w$ tej samej mierze, wobec innych narodów. Nie może zatem zamknać się $w$ pierwszej $z$ tych ról ${ }^{36}$. Nietrudno się więc dziwić, iż podobne przekonanie stało się udziałem Słoweńców, Chorwatów, Serbów, Boszniaków. Pozostałe nacje, choć z uwagi na swoja słabszą pozycję raczej nie mają co poszukiwać dla siebie roli liderów regionalnych, również usiłują zaznaczać swoją obecność, czego przykładem może być wspomniana kampania Kosowa.

Współpraca pomiędzy państwami byłej Jugosławii zaznacza się także w sferze gospodarczej. Pojawił się np. pomysł utworzenia wspólnych, bałkańskich linii lotniczych w miejsce Adria Airways, Croatia Airlines, Jat oraz Montenegro Airlines. Trzeba zauważyć, iż w ostatnich latach sukcesywnie wzrasta poziom bezpośrednich inwestycji zagranicznych, dokonywanych przez państwa byłej Jugosławii na obszarze dawnej federacji. Dzieje się to przede wszystkim

${ }^{34}$ Zob. np. A. Sepkowski, Poczqtki misji. Narodziny amerykańskiej „religii obywatelskiej”, Toruń 2008, s. 9.

${ }^{35}$ A. Curanović, Czynnik religijny w polityce zagranicznej Federacji Rosyjskiej, Warszawa 2010, s. 227, 294-295.

${ }^{36}$ Cyt. za: P. Grabowiec, Religia obywatelska jako teoretyczna propozycja integracji politycznej Wspólnoty Europejskiej, Wrocław 2013, s. 342. 
w sektorach energetycznym i bankowym oraz w handlu detalicznym, w którym to procesie wiodacca rolę odgrywają Lublana oraz Zagrzeb ${ }^{37}$. Natomiast Serbowie, choć posiadaja o wiele mniejsze możliwości, starają się - pewnie po części ze względów prestiżowych - przynależeć do klubu przewodzącego postjugosłowiańskiej integracji. Mówi się o stworzeniu jednej giełdy papierów wartościowych czy wspólnej linii kolejowej ${ }^{38}$. Można powiedzieć, iż obszar byłej Jugosławii stanowi dla tamtejszych przedsiębiorstw pewną całość, że ich działalność prowadzona jest ponad nowymi granicami. Przykładowo - w czerwcu 2013 r. większość udziałów w słoweńskim koncernie Merkator przejął chorwacki Agrokor, zaś rosyjska odpowiedź na unijne sankcje w sierpniu 2014 r. zrodziła w Chorwacji pomysły zakładania oddziałów w nieobjętej sankcjami Serbii ${ }^{39}$.

Motorem napędzającym współpracę stał się kryzys gospodarczy, zmuszający młode państwa do koncentracji na sprawdzonych rynkach regionu, gdzie ich produkty cieszą się dobrą opinia, sięgającą czasów federacji ${ }^{40}$. Ponadto często pojawiają się głosy, iż recesja poskutkuje ucieczką obcego kapitału z niestabilnych i niepewnych Bałkanów, jak ciagle myśli się o tamtych stronach, tak więc trzeba

${ }^{37}$ Western Balkan Integration and the EU. An Agenda for Trade and Growth, ed. S. Kathuria, Washington 2008, s. 77.

${ }^{38}$ Jugosfera: „Teoria spiskowa”, która stała się faktem, http://fakty.interia.pl/raport-srodek-wschod/opinie-artykuly-wywiady/news-jugosfera-teoria-spiskowa-ktora-stala-sie-faktem,nId,958663 (dostęp 24 III 2014).

${ }^{39} \mathrm{~J}$. Kerbler, Hrvati bi preko Srbije do ruskog tržišta, „Večernje novosti online", 9 VIII 2014, http://www.novosti.rs/vesti/naslovna/ekonomija/aktuelno.239.html:504683-Hrvati-bi-preko-Srbije-do-ruskog-trzista (dostęp 11 VIII 2014).

${ }^{40}$ D. Nišavić, Saradnja na prostoru bivše Jugoslavije neminounost, „Blic”, 1 XII 2009, http://www.blic.rs/Vesti/Drustvo/123260/Saradnja-na-prostoru-bivse-Jugoslavije--neminovnost (dostęp 19 III 2014). 
się liczyć z perspektywą bycia pozostawionymi samymi sobie.

Podobne argumenty można było usłyszeć w czasie powodzi, jakie nawiedziły w maju 2014 r. Serbię, Bośnię i Hercegowinę oraz w mniejszym stopniu Chorwację, kiedy z pomoca jako pierwsze pospieszyły państwa regionu. Wsparcie zadeklarowała również UE, ale wydanie stosownej decyzji zajęło jej - ze względów proceduralnych -30 godzin ${ }^{41}$. $\mathrm{Na}$ portalu Al Jazeera Balkans ukazał się artykuł o potrzebie regionalnej solidarności, bowiem, jak zauważa autor: Bruksela jest daleko, a sqsiad blisko ${ }^{42}$. Faktem jest, iż w obliczu trudnej sytuacji biedne społeczeństwa postjugosłowiańskie okazały się skłonne do natychmiastowej pomocy. Macedońscy abonenci telefonii komórkowej, w ciagu kilku godzin od uruchomienia specjalnego numeru, przekazali dla poszkodowanych 22 tys. euro. Kosowska wspólnota islamska przedsięwzięła zbiórkę darów dla bośniackich braci ${ }^{43}$. Warta podkreślenia jest postawa Chorwatów, którzy, sami zmagając się z powodzią w Slawonii, jednocześnie wspierali znajdujących się w dużo trudniejszej sytuacji sąsiadów ${ }^{44}$. Media opisywały łzy wzruszenia i dozgonną wdzięczność

${ }^{41}$ Brisel šalje pomoć u BiH i Srbiju, http://www.dw.de/brisel-\%C5\%A1alje-pomo\%C4\%87-u-bih-i-srbiju/a-17643311 (dostęp $18 \mathrm{~V}$ 2014).

${ }^{42}$ A. Nikolaidis, Opet solidarnost od Vardara do Triglava, http:// balkans.aljazeera.net/vijesti/opet-solidarnost-od-vardara-do-triglava (dostęp 18 V 2014).

${ }^{43}$ Zob. Kosovo: Pokrenuta humanitarna akcija "Prizren za Bosnu i Hercegovinu”, http://sandzakpress.net/kosovo-pokrenuta-humanitarna-akcija-prizren-za-bosnu-i-hercegovinu (dostęp $25 \mathrm{~V}$ 2014).

${ }^{44}$ Potrebna im je naša pomoć. Evo kako možemo pomoći žrtvama poplava, http://www.index.hr/vijesti/clanak/potrebna-im-je-nasa-pomoc-evo-kako-mozemo-pomoci-zrtvama-poplava/748082.aspx (dostęp 18 V 2014); http:// www.jutarnji.hr/foto--bandic--lijepo-je-danas-vidjeti-kamione-s-pomoci-na-kojima-pise-zagreb-za-beograd-/1194223/ (dostęp 27 V 2014). 
Serbów z Obrenovca dla chorwackich ratowników ${ }^{45}$, uwypuklały współpracę ludzi ponad narodowościowymi podziałami w Bośni i Hercegowinie. Na portalu B92 jeden z redaktorów zauważył, iż jeśli powodzie przyniosły temu krajowi coś dobrego, to było to zatopienie granic pomiędzy ludźmi - etnicznych, religijnych, entitetowych ${ }^{46}$.

Trzeba także podkreślić, iż to właśnie przede wszystkim w aspekcie gospodarczym mówić można o obecności odmiennego kulturowo Kosowa w procesie odradzania się dawnej SFRJ. Według danych z 2013 r., największym inwestorem w tym kraju była Słowenia ${ }^{47}$, zaś inne państwa regionu (przede wszystkim Chorwacja) starają się zwiększyć swoją obecność. W lutym 2014 r. serbskie oraz kosowskie przedsiębiorstwa energetyczne (Elektromreža Srbije i KOSTT) podpisały umowę o współpracy, będącą pierwszym tego typu dokumentem zawartym pomiędzy rzeczonymi krajami ${ }^{48}$.

Warto $\mathrm{w}$ tym miejscu zauważyć, iż proces integracji europejskiej również rozpoczął się od sfery gospodarczej. Osłabione wojną i upadkiem systemu kolonialnego państwa potrzebowały idei gwarantującej zapobiegnięcie kolejnemu konfliktowi, a rozpad imperiów kolonialnych potęgował pragnienia budowania potęgi, tym razem poprzez

${ }^{45}$ Hrvatski specijalci junaci Srbije: 'Plakao sam za vašim momcima', http://www.vecernji.hr/balkan/hrvatski-specijalci-junaci-srbije-plakao-sam-za-vasim-momcima-940741 (dostęp $27 \mathrm{~V}$ 2014).

${ }^{46}$ Voda „prekrila” $i$ granice među ljudima, http://www.b92.net/zivot/ vesti.php?yyyy=2014\&mm=05\&dd=25\&nav_id=852532 (dostęp 25 V 2014).

${ }^{47}$ Da li Hrvatska preuzima palicu „izaslanika” EU na Balkanu, „Политика Online”, 11 IX 2013, http://www.politika.rs/rubrike/Politika/ Hrvatska-preuzima-palicu-izaslanika-EU-na-Balkanu.lt.Da-li-html (dostęp 19 III 2014).

${ }^{48}$ Prvi sporazum dve kompanije iz Srbije i Kosova, http://www.euractiv.rs/energetika/6915-prvi-sporazum-dve-kompanije-iz-srbije-i-kosova (dostęp 19 III 2014). 
współpracę w ramach Starego Kontynentu, a dokładniej jego zachodniej części ${ }^{49}$. Analogie $\mathrm{z}$ Bałkanami wydają się nader znaczące, trywializmem będzie stwierdzenie, iż tamtejsze społeczeństwa muszą znaleźć sposób na jednoznaczne wyparcie wojny jako środka realizacji celów politycznych. Co do tego panuje w Unii powszechna zgoda. Przykładowo, na stronie austriackiego Ministerstwa Spraw Zagranicznych można przeczytać, iż z punktu widzenia Wiednia, istnieje tylko jeden sposób na zapewnienie Bałkanom Zachodnim długotrwałego pokoju, którym jest akcesja całego obszaru do $\mathrm{UE}^{50}$.

Powstałe na gruzach federacji kraje znaczą niewiele, a jedyną szansa na podniesienie przez nie swojego znaczenia i prestiżu na arenie międzynarodowej jest zjednoczenie sił, bowiem w dzisiejszych realiach tylko regionalna integracja stanowi możliwość włączenia się w globalna gospodarkę ${ }^{51}$. W literaturze często podkreśla się rozliczne korzyści takiej współpracy, mówi się np. o rozwoju technologicznym, wymianie naukowej, podnoszeniu poziomu edukacji, ochronie lokalnych kultur, współdziałaniu na rzecz bezpieczeństwa (m.in. przeciwdziałaniu zagrożeniom asymetrycznym). Te małe kroki mogą mieć fundamentalne znaczenie dla budowania wspólnoty wartości, która wyeliminuje wojnę jako środek prowadzenia polityki, na co zwracał uwagę np. Karl Deutsch ${ }^{52}$.

${ }^{49}$ J. Rifkin, Europejskie marzenie. Jak europejska wizja przyszłości zaćmiewa American Dream, Warszawa 2005, s. 250.

${ }^{50}$ Westbalkan - Ein Schwerpunkt der österreichischen Außenpolitik, http://www.bmeia.gv.at/aussenministerium/aussenpolitik/europa/westbalkan.html (dostęp 22 III 2014).

${ }^{51}$ P. Grabowiec, op. cit., s. 20.

${ }^{52}$ E. Stadtmüller, Unia Europejska a wspótpraca regionalna $w$ jej sqsiedztwie, [w:] Unia Europejska w XXI wieku. Polityczno-prawna wspólnota interesów, red. nauk. R. Riedel, Torun 2010, s. 265-266. 
Można prognozować, iż - podobnie jak to było w przypadku integracji europejskiej - współpraca gospodarcza stanie się zaczątkiem budowania porozumienia na płaszczyźnie politycznej. Symptomy tego obserwujemy już dziś, biorąc pod uwagę chociażby rosnąca współpracę regionalną. Jak zostało wcześniej zauważone, jej zasadniczym celem ma być wzajemne wspieranie się $\mathrm{w}$ procesie integracji europejskiej. W dniu przystapienia Chorwacji do UE (1 lipca 2013 r.) prezydent I. Josipović zorganizował śniadanie dla prezydentów: Serbii, Bośni i Hercegowiny, Czarnogóry, Macedonii, Albanii i Kosowa, na którym poruszano m.in. kwestie dalszego rozszerzenia Unii. Przywódcy zgodzili się, iż takie spotkania powinny stać się tradycja jako forma debaty na temat wspólnych problemów i interesów ${ }^{53}$. Rok później w Dubrowniku specjalnym gościem kolejnego, drugiego zjazdu była kanclerz Niemiec Angela Merkel, która wyraziła nadzieję, że przyjdzie taki dzień, kiedy wszystkie kraje regionu będą członkami Unii Europejskiej5.

Badacze są zgodni, iż „rehabilitacja” Jugosławii, oprócz współpracy ekonomicznej, odnosi się przede wszystkim do sfery kultury. Anna Jagiełło-Szostak zauważa, iż jugonostalgia stata się skomercjalizowana częścia popkultury ${ }^{55}$. Wielu badaczy podkreśla, że tej sfery lekceważyć nie wolno, bowiem kultura, podobnie jak ekonomia, potrafi zbliżać ponad politycznymi barierami. Przytacza się słowa jednego z inicjatorów integracji europejskiej - Jeana Monneta, który miał powiedzieć, iż gdyby

${ }^{53}$ Hrvatska u Evropskoj uniji, http://www.rts.rs/page/stories/sr/story/11/ Region/1351778/Hrvatska+u+Evropskoj+uniji.html (dostęp 9 VIII 2014).

${ }^{54}$ A.B. Leikauff, Sastanak predsednika država jugoistočne Evrope, http://www.funkhauseuropa.de/sendungen/radioforum/region/merkel_dubrovnik102.html (dostęp 8 VIII 2014).

${ }_{55}$ A. Jagiełło-Szostak, Idea narodu politycznego kontra etnonacjonalizmy. Od jugoslawizmu do jugonostalgii, Wrocław 2013, s. 292. 
mógł zaczać ów proces od nowa, rozpocząłby od kultury ${ }^{56}$. Podobne poglądy wygłaszają i inni, sugerując, że konsekwencja pominięcia tej sfery od samego początku budowania wspólnot jest dziś brak wspólnej europejskiej tożsamości ${ }^{57}$.

W literaturze coraz częściej mówi się o fenomenie kulturowej jugonostalgii, ale my na potrzeby niniejszego opracowania chcemy zając się tym, co Svetlana Slapšak określiła jako re-thinking Yugoslavia ${ }^{58}$, a więc mentalnych powrotów do idei wspólnotowości. Džemal Sokolović podkreśla, iż trzeba odróżnić tożsamość jugosłowiańską od koncepcji jugosłowiańskiego państwa, bowiem identyfikacja jugosłowiańska narodziła się jako alternatywa dla węgierskiego, austriackiego, czy tureckiego sąsiedztwa i wydawała się czymś naturalnym. Natomiast koncepcja wspólnej federacji od razu była naznaczona piętnem rywalizacji poszczególnych etnosów ${ }^{59}$. Nawet kręgi nacjonalistyczne wypowiadają się $\mathrm{w}$ podobnym tonie, dowodząc, że konflikty z lat 90 . XX w. były tym, co Europa przeżywała w XIX stuleciu (np. Wiosna Ludów) i że dopiero na poziomie państw narodowych możliwa jest efektywna współpraca. Wskazuje się na analogie z UE, gdzie niepodległe kraje kooperują ze sobą na coraz większą skalę. Taki punkt widzenia łączy wiarę w państwo narodowe z przekonaniami o konieczności otwarcia się na sąsiadów.

${ }^{56}$ G. Dziamski, Kultura w programach Unii Europejskiej. Od teorii do praktyki badań kulturoznawczych, [w:] Perspektywy badań nad kultura, pod red. R.W. Kluszczyńskiego i A. Zeidler-Janiszewskiej, Łódź 2008, s. 241.

${ }^{57}$ E. Brix, Inne znaczenie 1989 roku, „Herito. Dzedzictwo, kultura, współczesność" 2014, nr 15, s. 188.

${ }^{58}$ Z. Volcic, Post-socialist Recollections: Identity and Memory in Former Yugoslavia, [w:] Heritage, Memory and Identity, ed. by H.K. Anheier and Y.R. Isar, (seria: Cultures and Globalization, no. 4), London-Thousand Oaks-New Delhi 2011, s. 195.

${ }^{59}$ D. Sokolović, Nacija protiv naroda. Bosna je samo jedan slučaj, Beo$\operatorname{grad} 2006$, s. 238-249. 
Jeśli więc projekt polityczny okazał się fiaskiem, wyobrażenia o byciu wspólnotą wcale nie zanikły, a co więcej, dziś coraz silniej daja o sobie znać. Chorwacki dziennikarz i krytyk muzyczny, Ante Perković, dowodzi, że w ramach SFRJ istniała „siódma republika”, ponadnarodowa i transterytorialna, która jako jedyna przetrwała rozpad państwa ${ }^{60}$. Autor tych słów miał na myśli kulturowy dorobek Jugosławii i niewyobrażalne w bloku wschodnim otwarcie na świat, co może nie tylko stanowić powód do dumy ${ }^{61}$, ale również budzi tęsknotę za dawna świetnościa. Serbska badaczka - Radina Vučetić - spostrzega, iż to, co mieszkańcy Jugosławii oglądali w latach 60., Polacy oraz większość nacji za „żelazną kurtyną” mogli zobaczyć dopiero po upadku socjalizmu ${ }^{62}$. W 2002 r. belgradzkie Muzeum Historii Jugosławii zorganizowało wystawę Poslednja mladost u Jugoslaviji, poświęconą alternatywnej kulturze nowej fali w latach $1977-1984^{63}$. Tytuł, stanowiący kalkę nazwy albumu, wydanego w 1987 r. przez dwóch byłych członków grupy Idoli, nawiązuje do smutnego końca „złotego wieku" jugosłowiańskiej kultury.

We wrześniu 2014 r. serbski dziennik „Kurir” opublikował artykuł Sentimentalno podsećanje: 7 stvari zbog kojih smo voleli SFRJ (Sentymentalne wspomnienie: 7 rzeczy za które kochaliśmy SFRJ). Każdy z tytułowych siedmiu powodów odnosi się do idealizowanych aspektów, które po latach permanentnego kryzysu obrastaja legenda, wspierając mit

${ }^{60}$ A. Perković, Sedma republika. Pop kultura u Yu raspadu, ZagrebBeograd 2011, s. 21.

${ }^{61}$ Por. np. I. Čolović, Kultura i politika u Srbiji, [w:] Srbija je važna..., S. 141 .

${ }^{62}$ R. Vučetić, Koka-kola socijalizam. Amerikanizacija jugoslovenske popularne kulture šezdesetih godina XX veka, Beograd 2012, s. 246.

${ }^{63}$ Poslednja mladost u Jugoslaviji, http://www.dominomagazin.com/article/12375/art/poslednja-mladost-u-jugoslaviji (dostęp 30 III 2014). 
dostatniej i silnej Jugosławii. Zdaniem autora sa to: sukcesy w koszykówce; reklamy - dowód jugosłowiańskiego konsumpcjonizmu (jak zauważa autor, dziś również reklamy są na światowym poziomie, ale kraje nie mają już własnej produkcji, a odbiorca zachęcany jest do kupna zagranicznych towarów); telewizory i telewizja - symbol modernizacji i postępu; stołówki i bary szybkiej obsługi; zakupy - wspomnienie jugosłowiańskiego konsumpcjonizmu i relatywnie wysokiego standardu życia; magazyny erotyczne - symbol otwartości kultury na wpływy zachodnie; festiwale muzyczne w Opatiji, Zagrzebiu, Belgradzie, Sarajewie, Splicie, które urastały do rangi wielkich wydarzeń i jako takie na trwale zapisały się $\mathrm{w}$ wyobrażeniach zbiorowych ${ }^{64}$. Nietrudno skonstatować, że przytaczane w owym tekście wycinki jugosłowiańskiej rzeczywistości odnoszą się do jej społecznej, a nie politycznej płaszczyzny, zaś autor, choć nie wyraża tego wprost, ciepło odnosi się do wielokulturowego i bogatego kraju, w którym żyło się dobrze i wygodnie.

Na obszarze byłej Jugosławii często mówi się o przegranych pokoleniach - na określenie osób urodzonych pomiędzy latami 50. a 80., które wychowywały się w wieloetnicznym państwie, gdzie poziom życia przewyższał nawet niektóre państwa Europy Zachodniej. W 2000 r. dyrektor chorwackiego oddziału Microsoftu, Goran Radman, stwierdził: Na poczatku lat 90. Jugostawia, pod względem rozwoju technologii informacyjnej i wiedzy o komputerach, wyprzedzała Wtochy i Austrie (nie mówiqc o bytych radzieckich satelitach we Wschodniej Europie), prawie każde większe przedsiębiorstwo posiadało centrum komputerowe $i$ informatyków $z$ odpowiednim przygotowaniem

${ }^{64}$ M.M. Popović, 7 stvari zbog kojih smo voleli SFRJ, „Kurir”, 20 IX 2014, http://www.kurir-info.rs/vesti/drustvo/7-stvari-zbog-kojih-smo-voleli-sfrj-clanak-1563291 (dostęp 22 IX 2014). 
$i$ sprzętem. To byta nasza trampolina do pomyślnej i szybkiej tranzycji. A tak, jesteśmy w tyle za Rumunia $i$ Butgaria ${ }^{65}$. To porównanie posiada znacząca wymowę, biorąc pod uwagę wyższość, jaką odczuwali kiedyś mieszkańcy Jugosławii wobec ubogich sasiadów ze wschodniej strony Bałkanów. Ci, przybywając do SFRJ, traktowali ją jako Zachód - nie tylko ze względu na wyższy poziom życia, ale również doświadczali namiastki wolności, korzystając z płynącej szeroką falą amerykańskiej i europejskiej kultury ${ }^{66}$. Świadomość bycia dziś w tyle za Bułgarią i Rumunią dodatkowo potęguje frustracje z powodu chaosu ciagle przedłużającej się transformacji.

Dekada wojen, trudna sytuacja ekonomiczna i permanentny kryzys, trwający aż po dziś, przyczyniły się do sukcesywnego odpływu najlepiej wykształconej i najzaradniejszej części bałkańskich społeczeństw. Pośród postjugosłowianskiej imigracji panuje pozytywny stosunek do dawnego państwa. Co więcej, diaspora, pielęgnująca mit fenomenu szczęśliwej i dostatniej federacji, wspiera procesy integracyjne i odradzanie się coraz szerszej sieci powiązań na obszarze dawnej SFRJ ${ }^{67}$.

Dlatego śmierć Jugosławii wcale nie musi oznaczać upadku idei współpracy, tym bardziej, że ciagle żywe są wyobrażenia o sukcesach odnoszonych przez federację, szczególnie w takich aspektach, jak: polityka zagraniczna, modernizacja, osiagnięcia kulturowe i sportowe. Rozumiejąc coraz częściej potrzebę współdziałania, także ze względów pragmatycznych, bowiem ponadnarodowe przedsięwzięcia są chętnie finansowane przez Brukselę ${ }^{68}$, obserwujemy rozkwit tego typu

${ }^{65}$ Cyt. za: V. Perica, Balkanski idoli. Religija i nacionalizam u jugoslovenskim državama, [t.] 2, Beograd 2006, s. 188.

${ }^{66}$ R. Vučetić, op. cit., s. 177.

${ }^{67}$ V. Perica, Generacije protiv nacija. Postjugoslavenski diskursi heroizma, [w:] V. Perica, M. Velikonja, op. cit., s. 247-248.

${ }^{68}$ M. Lasić, Europe Now - Europa sada ili nikada, Sarajevo 2011, s. 481. 
inicjatyw. Jako przykład może służyć projekt CROSS SPA, realizowany na pograniczu Serbii oraz Bośni i Hercegowiny, którego celem ma być rozwój turystyki uzdrowiskowej ${ }^{69}$.

W 1999 r. były trener reprezentacji Jugosławii w koszykówce, Bogdan Tranjević, zaproponował założenie wspólnej ligi dla państw dawnej federacji - jako krok mający na celu pojednanie zwaśnionych narodów. Inicjatywa zdobyła aprobatę społeczności międzynarodowej, która zgodziła się finansować rozgrywki ${ }^{70}$. Dzięki temu w 2001 r. ruszyła tzw. Jadranska Liga, przemianowana w 2011 r. na ABA liga (Adriatic Basketball League). Idea, choć początkowo krytykowana przez nacjonalistów (przede wszystkim w Chorwacji) jako krok w stronę restytucji Jugosławii, tak dobrze przyjęła się na Bałkanach, że zaczęły powstawać podobne pomysły (np. od 2008 r. istnieją regionalne rozgrywki w piłce wodnej - Jadranska vaterpolska liga). W 2010 r. Deutsche Welle podało informację, że Serbia, Chorwacja oraz Bośnia i Hercegowina planuja starania o wspólną organizację Mistrzostw Europy $\mathrm{w}$ piłce nożnej w $2020 \mathrm{r}^{.11}$ I choć od pomysłu zdystansowali się bałkańscy działacze sportowi i politycy, a opinia publiczna zastanawiała się, skąd biedne państwa wzięłyby na ten cel pieniądze ${ }^{72}$, koncepcja wspólnego turnieju - jako szansy zbliżenia narodów - pozostaje ciagle żywa i pojawia się czasem

${ }^{69}$ Razvoj i promocija zdravstvenog turizma u prekograničnom području Srbija - Bosna i Hercegovina-CROSS SPA, http://www.fld.ba/stranica/ razvoj-i-promocija-zdravstvenog-turizma-u-prekograninom-podruju-srbijabosna-i-hercegovina-cross-spa (dostęp 22 III 2014).

${ }^{70}$ V. Perica, Balkanski idoli...., s. 184-185.

${ }^{71}$ Zob. np. EP 2020. u Srbiji, BiH i Hrvatskoj?, http://www.pressonline.rs/sport/fudbal/124428/ep-2020-u-srbiji-bih-i-hrvatskoj.html (dostęp 11 VIII 2014).

${ }^{72}$ Daleko od Europskog prvenstva, „Večernje novosti”, 5 VII 2010, http://www.naslovi.net/2010-07-05/vecernje-novosti/daleko-od-evropskog-prvenstva/1834287 (dostęp 11 VIII 2014). 
w prognozach dotyczących perspektyw zacieśniania współpracy regionalnej.

Co roku studenci ze Słowenii, Chorwacji, Bośni i Hercegowiny, Serbii, Czarnogóry, Macedonii biorą udział w sześciodniowych imprezach Gradevinijada (dla słuchaczy budownictwa, architektury, geodezji) i Medicinijada (dla słuchaczy kierunków medycznych), gdzie oprócz wykładów i warsztatów odbywaja się zawody sportowe. Obie inicjatywy, z których każda przyciaga ponad tysiąc uczestników, z powodzeniem odbywały się również w okresie istnienia Jugosławii i - jak widać - idea integracji młodych ludzi okazała się silniejsza niż polityczne podziały. Formuła przedsięwzięcia zakłada, iż co roku organizacją spotkania zajmuje się inny wydział i, co ciekawe, zdarza się, że na miejsce imprezy wybierana jest miejscowość leżąca w innym państwie regionu. Przykładowo - Wydział Budownictwa i Architektury w Nišu, pełniąc rolę gospodarza Građevinijady, wybrał na miejsce jej organizowania w 2007 r. Ohryd ${ }^{73}$, a w 2014 r. Budvę ${ }^{74}$.

Inną inicjatywa, jaka wyszła ze strony młodych ludzi, są odbywające się od 2007 r. Dni Sarajewa w Belgradzie, mające być formą swojego rodzaju zadośćuczynienia i pojednania. Festiwal, promując współpracę pomiędzy oboma miastami, przyznaje corocznie nagrodę za upowszechnianie pokojowego dialogu ${ }^{75}$. Z kolei niemiecki dziennikarz, Erich Rathfelder, podkreśla szczególne związki pomiędzy Sarajewem i Dubrownikiem, korzeniami sięgające średniowiecza (handel z republiką kupiecka) i trwale umocnione wydarzeniami z lat $90 . \mathrm{XX}$ w., kiedy oba miasta

${ }^{73}$ http://www.gaf.ni.ac.rs/spgaf/_news/dc/gradjevinijada/index.htm (dostęp 5 VI 2014).

${ }^{74}$ http://grad.hr/stzbor/gradevinijada-2014-8-5-13-5/ (dostęp 5 VI 2014).

75 'Dani Sarajeva u Beogradu': Nagrada Biljani Srbljanović, http:// www.radiosarajevo.ba/novost/155342/dani-sarajeva-u-beogradu-nagrada-biljani-srbljanovic\# (dostęp 16 VI 2014). 
doświadczyły dramatu oblężenia. Jak podkreśla Rathfelder, mieszkańcy Dubrownika odnoszą się do bośniackich turystów z wielką sympatia, bez negatywnych stereotypów ${ }^{76}$.

Brytyjski dziennikarz, Tim Judah, używając w swoim słynnym eseju z 2009 r. pojęcia ,jugosfera”, wywołał na Bałkanach szeroka dyskusję. Podobne kontrowersje budzi powszechny w dyskursie zewnętrznym (również w Polsce) termin „Bałkany Zachodnie”, na co zwraca uwagę serbska antropolożka Tanja Petrović, określając go jako sztuczny i niezgodny z autoidentyfikacją większości tamtejszych nacji ${ }^{77}$. Katarina Luketić dodaje zaś, że wprawdzie wykreowane przez Unię Europejską określenie spotkało się z ostrą krytyka, zwłaszcza w Chorwacji, to przyjęło się ono w świecie zewnętrznym $^{78}$. Ale - jak wykazuja niektórzy badacze - wykreowanie pojęcia „Bałkany Zachodnie” mogło mieć głębszy sens, wynikający z aspektów psychologicznych. Odnosi się ono bowiem do zachodniej tożsamości społeczeństw regionu (szczególnie Chorwatów, czy Serbów), a także stanowi potwierdzenie ich wewnętrznego przekonania o byciu przedmurzem Europy. Ponadto logika terminu „Bałkany Zachodnie” mówi, że Bułgaria i Rumunia to wschodnia część półwyspu, a skoro kraje te już są w UE, Bałkany Zachodnie tym bardziej powinny do niej należeć. To tylko kwestia czasu ${ }^{79}$.

${ }^{76}$ E. Rathfelder, Raskrsnica Sarajevo. Bosna i Hercegovina deset godina poslije Daytona: muslimani, pravoslavci, katolici i jevreji grade zajedničku državu, Tuzla 2007, s. 90.

${ }^{77}$ T. Petrović, Yuropa. Jugoslovensko nasleđe i politike budućnosti u postjugoslovenskim društvima, Beograd 2012, s. 21-36.

${ }^{78}$ K. Luketić, Balkan: od geografije do fantazije, Zagreb-Mostar 2013, s. $188-190$.

${ }^{79}$ L. Šarić, Domestic and Foreign Media Images of the Balkans, [w:] Contesting Europe's Eastern Rim, ed. by L. Šarić, A. Musolff, S. Manz and I. Hudabiunigg, Bristol-New York-Ontario 2010, s. 61. 
Tutaj ocieramy się o utrwaloną w wyobrażeniach zbiorowych dychotomię Wschód-Zachód. Tomasz Zarycki zauważa, iż choć wiele mówi się w UE o zaniku granic, ciagle dominuje wartościowanie, jakoby zachodnia część Starego Kontynentu była lepsza, a wschodnia - gorsza ${ }^{80}$. Kaja Kaźmierska dodaje zaś, że ubocznym skutkiem idei integracji europejskiej jest mentalne wykluczenie obszarów Starego Kontynentu nienależących do Unii ${ }^{81}$.

Nie zmienia to jednak faktu, iż mieszkańcy byłej Jugosławii preferują określenie „Europa Południowo-Wschodnia”, które również przyznaje im prawo do bycia Europejczykami i posiada mniej peryferyjne konotacje. Zdaniem Bogusława Zielińskiego, sugeruje ono zapowiedź stabilizacji i lepszej przyszłości ${ }^{82}$. Ale dla większości mieszkańców tamtego obszaru słowo „stabilizacja” kojarzy się z titowską Jugosławia. Todor Kuljić podkreśla, że takie wspomnienia rodzą krytyczny stosunek względem okresu transformacji i towarzyszących mu niedogodności ${ }^{83}$.

Mitja Velikonja, prowadząc we wspomnianym eseju rozważania na temat jugonostalgii we współczesnej słoweńskiej muzyce, zamieścił aneks z wykazem zespołów i stopniem wykorzystania przez nie motywów SFRJ, który zajął mu niewiele ponad trzy strony, co dobitnie pokazuje skalę fenomenu.

${ }^{80}$ T. Zarycki, Polskie dyskursy o „Wschodzie” wewnętrznym i zewnętrznym - próba analizy krytycznej, [w:] Polska Wschodnia i orientalizm, red. nauk. T. Zarycki, Warszawa 2013, s. 187.

${ }^{81} \mathrm{~K}$. Kaźmierska, Rola pamięci zbiorowej we wspótczesnym spoteczeństwie - czy tatwo ja określić?, [w:] Przeszłość w dyskursie publicznym, pod red. A. Szpocińskiego, Warszawa 2013, s. 33.

${ }^{82}$ B. Zieliński, Obraz Stowiańszczyzny południowej w polskim dyskursie publicznym III Rzeczypospolitej (po 1989 roku), [w:] Tradycje pogranicza $i$ przestrzenie tradycji. Od komunizmu do postmodernizmu i postkoloniali$z m u$, red. nauk. B. Zieliński, Poznań 2008, s. 47.

${ }^{83}$ T. Kuljić, Sećanje na titoizam. Između diktata i otpora, Beograd 2011, s. 12 . 
Podobne przykłady odnajdujemy również w innych krajach. Wystarczy wspomnieć chociażby takie postacie, jak: Rambo Amadeus, Tijana Dapčević, Đorđe Balašević. Słynny serbski festiwal EXIT odbywa się już nie tylko w Nowym Sadzie, jego druga część - pod nazwą SEA DANCE FESTIVAL - organizowana jest w czarnogórskiej Budvie ${ }^{84}$. W Lublanie ma swoja siedzibę MTV Adria - muzyczny kanał telewizyjny, odbierany „od Wardaru po Triglav”. Ów zwrot ku Bałkanom tłumaczyć można nie tylko rzeczywistą tęsknotą za wspólnym państwem. Należy również wziąć pod uwagę, dającą się zauważyć chyba w każdym społeczeństwie, krytykę procesów globalizacyjnych i westernizacji. Jednym ze sposobów manifestowania takich postaw jest kultura protestu ${ }^{85}$, czyli w tym wypadku zwrócenie się ku jugosłowiańskiej przeszłości.

Ciekawe wyjaśnienie owego fenomenu proponuje Ivan Čolović. Jego zdaniem, fakt, iż w Serbii producenci i twórcy muzyki reklamuja jej miejsce pochodzenia jako Bałkany, motywowany jest postrzeganiem na Zachodzie tegoż terytorium niczym zapóźnionego cywilizacyjnie, ale przez to nieskażonego procesami modernizacyjnymi, gdzie uchować się miała szansę autentyczna kultura ${ }^{86}$. Spostrzeżenie belgradzkiego antropologa odnosi się do obrazu Bałkanów w świecie zewnętrznym, ale przecież Velikonja, mówiąc o nowym jugoslawiźmie, nie ograniczał się wyłącznie do sukcesorów dawnej SFRJ.

Afektywny stosunek do komunistycznej Jugosławii wyrażają również samoorganizujące się chóry, które, jak zauważa

${ }^{84} \mathrm{http} / / /$ www.exitfest.org/en/adventure (dostęp 26 IV 2014).

${ }^{85}$ A. Cybal-Michalska, Globalizacja i jej krytyka. O potrzebie zorientowania społeczeństwa na wiedzę, aktywne współdziałanie $i$ odpowiedzialność, [w:] Dyskursy kultury popularnej w społeczeństwie współczesnym, red. nauk. A. Cybal-Michalska, P. Wierzba, Kraków 2012, s. 23-24.

${ }^{86}$ I. Čolović, Etno. Opowieści o muzyce świata w Internecie, przeł. M. Petryńska, Sejny 2012, s. 286-287. 
T. Petrović, nie są wyłącznie specyfiką obszaru postjugosłowiańskiego. W ostatnim czasie obserwujemy znaczacy wzrost ich liczby, a także wzajemną współpracę ${ }^{87}$. Chóry, angażujące przede wszystkim ludzi młodych, wykonuja m.in. utwory rewolucyjne i stare pieśni partyzanckie, odgrywają istotną rolę w upowszechnianiu idei społecznego zaangażowania w państwach postjugosłowiańskich, a także przyczyniają się do ożywiania współpracy w ramach dawnej federacji ${ }^{8}$. Silnie eksponowana ideologia antyfaszyzmu znajduje swoje odzwierciedlenie nie tylko w powoływaniu się na titowską retorykę, ale również $\mathrm{w}$ aktywnym udziale $\mathrm{w}$ manifestacjach skierowanych przeciwko radykalnej prawicy ${ }^{89}$. Nadto grupy te potępiają nacjonalizm i wojnę, promując jedność między narodami. Warto podkreślić, iż niektóre z nich, np. Hor Le Zbor z Zagrzebia czy Le wHORe z Belgradu, skupiaja w swoich szeregach lesbijki, a przecież walka o równouprawnienie mniejszości seksualnych, jak i pacyfizm to postulat nowej lewicy. Bez wątpienia, chóry, osobliwa forma kultury alternatywnej, rytualizując stare jugosłowiańskie mity upowszechniaja pozytywny obraz SFRJ, a ich rosnące popularność i aktywność sprawiaja, że hasła o szczęśliwym i dostatnim życiu w „braterstwie i jedności” trafiają do coraz większej liczby odbiorców.

Przykładem ciepłego wspomnienia o Jugosławii jest wystawa Živeo život (Niech żyje życie), otwarta w czerwcu 2013 r. w Belgradzie ${ }^{90}$, gdzie zwiedzający mogą oglądać przedmioty

${ }^{87}$ T. Petrović, op. cit., s. 137.

${ }^{88}$ M. Sretenović, Hiphopere ljudi ne uzimaju „za ozbiljno”, „Politika”, 28 V 2011, http://www.politika.rs/rubrike/Kulturni-dodatak/Hiphopere-ljudi-ne-uzimaju-za-ozbiljno.lt.html (dostęp 1 IV 2014).

${ }^{89}$ T. Petrović, op. cit., s. 138-139.

${ }^{90}$ Po Belgradzie wystawa przewieziona została do Słowenii. W maju 2014 r. powróciła do Serbii, tym razem do Nowego Sadu. Planowane jest jej dalsze tournée po miastach byłej Jugosławii. 
codziennego użytku z okresu SFRJ, a także zapoznać się z materiałami filmowymi, pokazującymi życie $\mathrm{w}$ dawnym państwie $^{91}$. Wiele miejsca zostało poświęcone sukcesom sportowym, przede wszystkim w koszykówce ${ }^{92}$, a przecież aspekt ten stanowi jeden z najczęściej przywoływanych dowodów na rzecz potęgi państwa jugosłowiańskiego. Dzięki niemu o Jugosławii ciagle było głośno w pozytywnym kontekście ${ }^{93}$. Gregor Starc podkreśla, że od samego początku w jugosłowiańskiej telewizji istotne miejsce zajmowały transmisje imprez sportowych, które gromadziły przed odbiornikami sasiadów i znajomych ${ }^{94}$. Takie chwile, pełne kolektywnie przeżywanych emocji, łatwo zakorzeniaja się w wyobrażeniach zbiorowych, a po latach powracają w postaci sentymentalnych wspomnien. Warto zwrócić uwagę na wymowę tytułu Živeo život, sugerująca, iż w czasach socjalistycznego państwa żyło się lepiej.

Jugosławia i jej tragiczny rozpad stały się wiodącym motywem najnowszej książki słoweńskiego pisarza i reżysera, Gorana Vojnovicia - Jugoslavija, Moja dežela (Jugostawia, mój kraj), co wzbudziło dyskusję na temat powrotu do dawno zamkniętego rozdziału. W wywiadzie dla gazety „Primorske novice" autor stwierdził, iż nie chce być nazywany jugonostalgikiem, ale kulturowym jugofilem, bowiem obszar byłej

${ }^{91}$ B. Damnjanović, Predmeti iz suakodnevice $i$ simboli života u SFRJ na izložbi „Živeo život”, „Blic”, 5 VI 2013, http://www.blic.rs/Vesti/Beograd/386283/Predmeti-iz-svakodnevice-i-simboli-zivota-u-SFRJ-na-izlozbi-Ziveo-zivot (dostęp 28 III 2014); http://www.ziveozivot.com/ (dostęp 28 III 2014).

${ }_{92}$ M. Tucaković, „Živeo život”, drugi deo, http://www.rts.rs/page/stories/ sr/story/16/Kultura/1473094/\%22\%C5\%BDiveo+\%C5\%BEivot\%22,+drugi+deo.html (dostęp 19 IV 2014).

${ }^{93}$ M. Petryńska, „Skrócona” ojczyzna, „Literatura na świecie” 1994, nr 11, s. 326.

${ }^{94}$ G. Starc, Sportsmen of Yugoslavia, Unite: Workers' Sport between Leisure and Work, [w:] Remembering Utopia: The Culture of Everyday Life in Socialist Yugoslavia, ed. by B. Luthar and M. Pušnik, Washington 2010, s. 280. 
SFRJ ciagle funkcjonuje jako jedna sfera kulturowa ${ }^{95}$. Podobne poglądy wygłaszało wielu intelektualistów i to tuż po rozpadzie federacji ${ }^{96}$. Przykładowo, słoweński pisarz - Drago Jančar - stwierdził: Kocham Dalmacje [...], antyk, renesans, ciszę ogrodów w katolickich ogrodach na wyspach. Rzeki Bośni, symbioza kultur $w$ Sarajewie, gwar $i$ ścisk wschodniego targowiska [...]. Biblijna Macedonia [...]. Belgrad $i$ jego niespożyta żywotność [...]. Morawa, stowiańskie pieśni przy wtórze orientalnych bębenków. I w końcu Zagrzeb [...] ze wzrokiem utkwionym $w$ Wiedniu, ale obiema nogami stojacy na Batkanach ${ }^{97}$.

Trzeba podkreślić, iż Jančar - represjonowany przez komunistyczny reżim oraz aktywnie zaangażowany $\mathrm{w}$ działalność opozycyjna - nie miał powodów, by żałować SFRJ, obiektem jego tęsknoty jest więc wspólne państwo, a nie jego ustrój. Odbiciem poglądów Jančara jest wydana niedawno w Polsce książka Widziałem ja tej nocy, opisująca z jednej strony jugosłowiańską mozaikę, przenikanie się orientu i zachodniego stylu życia, a z drugiej stawiająca w negatywnym świetle komunistycznych partyzantów. Wielu intelektualistów do tej pory zastanawia się, dlaczego nie udało się ocalić jedności, dlaczego rozbuchany nacjonalizm szerzyt się jak pożar - jak to określiła Slavenka Drakulićp8.

${ }^{95}$ Ne jugonostalgiji, da kulturni jugofiliji, „Primorske novice”, 24 XI 2011, http://www.primorske.si/Kultura/Ne-jugonostalgiji-da-kulturni-jugofiliji.aspx (dostęp 30 III 2014).

${ }^{96}$ M. Petryńska, op. cit., s. 326.

${ }^{97}$ Cyt. za: J. Pszczoła, Być Stoweńcem, być Stowianinem, być Europejczykiem. Relacje między polityka, kulturq a literatura, [w:] Poznać Batkany. Historia - polityka - kultura-języki. IV, pod red. K. Taczyńskiej i A. Twardowskiej, Toruń 2012, s. 381.

${ }^{98} \mathrm{~S}$. Drakulić, Oni nie skrzywdziliby nawet muchy. Zbrodniarze wojenni przed Trybunałem w Hadze, przeł. J. Szacki, Warszawa 2006, s. 9. 
Często można spotkać pogląd, że Jugosławia była prekursorką dzisiejszej Unii Europejskiej, biorąc pod uwagę wielonarodowość, wielokulturowość, a także bezpieczeństwo socjalne. Chorwacki reżyser i dziennikarz, Predrag Lucić, w jednym z wywiadów stwierdził, iż Jugostawia była nasza pierwsza UE. Ze swoimi dobrymi i złymi stronami. I marzyli o niej najlepsi, tak jak dziś o UE [...]. Niestety, na obszarze byłej SFRJ dzisiaj więcej jest takich, którym pojęcie region bliższe jest niż Jugostawia ${ }^{99}$. W tym miejscu wyjaśnić trzeba, iż termin regija na trwałe zakotwiczył się w przestrzeni postjugosłowiańskiej. Portale internetowe dzielą informacje czy prognozę pogody na kraj, region i świat. Podobnie czynią supermarkety, a nawet niektóre księgarnie, segregując odpowiednio towary na półkach.

Jak wcześniej zauważono, nowy jugoslawizm rozpatrywać można również $\mathrm{w}$ aspekcie zewnętrznym, biorąc pod uwagę stosunek innych względem SFRJ. Eric Gordy zwraca uwagę, iż w okresie „zimnej wojny” Jugosławia stanowiła dla amerykańskiej lewicy dowód na to, że „trzecia droga” jest możliwa, a kapitalizm nie jest jedynym sposobem osiagnięcia dobroby$\mathrm{tu}^{100}$. Podobne przekonania panowały w Europie Zachodniej, tym bardziej, że wielu jej mieszkańców spędzało wakacje na jugosłowiańskich plażach. Warto podkreślić, iż eksperyment Jugosławii stanowić mógł dla świata zachodniego nadzieję, że komunistyczna utopia jest jednak do zrealizowania. Andrzej Sepkowski zwraca uwagę na fascynację światowych intelektualistów nowym porządkiem, budowanym w Związku

${ }_{99}$ Predrag Lucić: Jugoslavija je bila naša EU - sanjali su je najbolji, a srušili najgori, http://tacno.net/novosti/predrag-lucic-jugoslavija-je-bila-nasa-eu-sanjali-su-je-najbolji-a-srusili-najgori/ (dostęp 28 IX 2014).

${ }^{100}$ E. Gordi, Jedno sasvim lično sećanje na hladni rat, Jugoslaviju i jeftino (ali dobro) vino, [w:] Zid je mrtav, živeli zidovi! Pad Berlinskog zida i raspad Jugoslavije, ur. I. Čolović, Beograd 2009, s. 357-359. 
Radzieckim, która szybko okazała się bezpodstawna ${ }^{101}$. Wiara w możliwość budowy lepszego, sprawiedliwego świata trwała jednak nadal w kręgach lewicowych, co pokazało m.in. poparcie dla Czerwonych Khmerów ${ }^{102}$. Nietrudno więc zrozumieć, iż Jugosławia urosła do rangi socjalistycznego wzorca. Zreszta i dziś europejska lewica upatruje przyczyn krwawego rozpadu państwa w zaprzepaszczeniu titowskich ideałów.

Bułgarski politolog, Ivan Krastev, zauważa, że po upadku komunizmu Jugosławia z dnia na dzień przestała być modna, że w jej idee przestali wierzyć zarówno tamtejsi politycy, jak i cały świat ${ }^{103}$. Chyba jednak nie do końca. Słoweński badacz, Matjaž Klemenčič, stwierdza, że sympatie europejskiej lewicy przekształciły się z projugosłowiańskich na proserbskie, co znalazło swoje odbicie na forum Parlamentu Europejskiego ${ }^{104}$. Richard Caplan dowodzi, że państwa rządzone przez socjalistów nie były poczatkowo przychylne niepodległości Chorwacji $^{105}$. Trzeba pamiętać, iż S. Milošević kreował się na obrońcę idei jugosłowiańskiej, a taka argumentacja trafiała do wielu, przerażonych tragicznym finałem państwa, w które tak wierzyli. Inni z kolei angażowali się emocjonalnie po stronie Serbów z przekory, tylko dlatego, że światowa opinia publiczna była przeciwko nim. Na przykład Peter Handke, uznawany za

${ }^{101}$ A. Sepkowski, Zbawić się na ziemi. O soteriologii immanentnej, Łódź 2014, s. 181-182.

${ }^{102}$ P. Fröberg Idling, Uśmiech Pol-Pota (o pewnej szwedzkiej podróży przez Kambodże Czerwonych Khmerów), przeł. M. Kalinowski, Wołowiec 2010, s. 192-194.

${ }^{103}$ I. Krastev, Opasne analogije, [w:] Srbija je važna..., s. 133.

${ }^{104} \mathrm{M}$. Klemenčič, The International Community and the FRY/Belligerents, 1989-1997, [w:] Confronting the Yugoslav Controversies. A Scholars' Initiative, ed. by Ch. Ingrao and T.A. Emmert, 2nd ed., West Lafayette 2013, s. 165.

${ }^{105}$ R. Caplan, Europe and the Recognition of New States in Yugoslavia, Cambridge-New York 2005, s. 107. 
jednego z najlepszych współczesnych austriackich pisarzy, nie tylko ostentacyjnie popierał Miloševicia, ale również odwiedzał Serbię i był obecny na pogrzebie serbskiego polityka ${ }^{106}$. Jego książka Podróż zimowa nad Dunaj, Sawę, Morawę i Drinę albo sprawiedliwość dla Serbii próbuje tłumaczyć serbskie racje ${ }^{107}$. Warto na marginesie nadmienić, że ostre polemiki obrońców i krytyków Handkego koncentrują się na aspekcie politycznym czy moralnym, zarzuca mu się naiwność i brak znajomości realiów. Rzadko jednak wspomina się jedną z zasadniczych myśli pisarza, że obrazy mogą kłamać, że wojenni reporterzy dobierają zdjęcia i relacje do gotowych tez ${ }^{108}$, co obserwujemy przy wszystkich konfliktach, nie tylko bałkańskich.

Wydaje się, że fascynacja jugosłowiańską wersją ustroju ożyła w dyskursie zachodniej lewicy, a tragiczny rozpad federacji przedstawiany bywa jako rezultat odejścia od ideologii braterstwa i jedności. Często można spotkać pogląd, iż skoro dało się przez kilkadziesiąt lat utrzymać w całości wieloetniczną mozaikę, oznacza to, że idea jedności nie jest bezzasadna. I choć zazwyczaj eksperci, głoszący takie slogany, o Bałkanach przeważnie niewiele wiedza, faktem pozostaje pozytywne postrzeganie Jugosławii w kręgach lewicowych.

W końcu 2013 r. niemiecki analityk, Cornelius Adebahr, wywołał na Bałkanach goracą dyskusję, zastanawiając się, ile zyskałby świat, gdyby nie nastapił rozpad SFRJ. Europa nie skompromitowałaby się swoją niemoca i podziałami, Stany Zjednoczone nie musiałyby interweniować (z którego to powodu Stary Kontynent do dziś odczuwa traumę), Jugosławia

${ }^{106}$ M. McDonald, The Apologist, http://theamericanscholar.org/the-apologist/\#.U-oWbWPUc-A (dostęp 12 VIII 2014).

${ }^{107}$ Por. np. K. Doubt, Sociologija nakon Bosne, Sarajevo 2003, s. 93-106.

${ }^{108}$ S.P. Ramet, Thinking about Yugoslavia. Scholarly Debates about the Yugoslav Breakup and the Wars in Bosnia and Kosovo, Cambridge 2005, s. 147-148. 
od dawna byłaby członkiem UE, a jej silna pozycja w ruchu państw niezaangażowanych pomogłaby rozwijać współpracę gospodarcza z Indiami, Malezja, Indonezja, RPA ${ }^{109}$. Szwedzki piłkarz o bośniackich korzeniach, Zlatan Ibrahimović, stwierdził natomiast, iż żałuje, że dzisiaj nie występuje jedna reprezentacja narodowa, bowiem miałaby ona o wiele większe szanse niż rozdrobnione ekipy nowych państw ${ }^{110}$.

Wydaje się, iż wraz z biegiem czasu Jugosławia będzie coraz bardziej idealizowana, zarówno w dyskursie wewnętrznym, jak i zewnętrznym. Mając na uwadze, iż pamięć jest zawodna, że postmodernistyczny człowiek przyjmuje historię $\mathrm{w}$ postaci pastiszu, należy oczekiwać, iż mit dostatniej, wieloetnicznej Jugosławii będzie się dalej umacniał. Państwa postjugosłowiańskie zrozumiały, że samodzielnie nie mają większych szans rozwoju, a w XXI w. kluczowe znaczenie posiada współpraca regionalna. Kulturowa bliskość południowych Słowian, która przed laty fascynowała elity, ciagle okazuje się czynnikiem zbliżajacym spoleczeństwa. Tym samym chyba trzeba przyznać rację badaczom sugerującym, że koncepcja Jugosławii jako państwa zakończyła się fiaskiem, ale to nie znaczy, że współpraca krajów sukcesyjnych nie jest możliwa. Co więcej, wydaje się ona nieodzowna, biorąc pod uwagę trend współpracy regionalnej w Europie. W takim kontekście „europejska perspektywa” łączy się z koniecznością kooperacji wszystkich sukcesorów dawnej SFRJ ${ }^{111}$.

${ }^{109}$ SFRJ se 1991. nije raspala, nego je krenula ka EU. Evo kako bi izgledala istorija da je to istina, „Blic”, 21 XII 2013, http://www.blic.rs/Vesti/ Politika/429113/SFRJ-se-1991-nije-raspala-nego-je-krenula-ka-EU-Evo-kako-bi-izgledala-istorija-da-je-to-istina (dostęp 8 VIII 2014).

${ }^{110}$ Ibrahimović: Jugoslavija bi imala neverovatan tim da se nije raspala, „Kurir”, 22 XII 2013, http://www.kurir-info.rs/ibrahimovic-jugoslavija-bi-imala-neverovatan-tim-da-se-nije-raspala-clanak-1146791 (dostęp 8 VIII 2014).

${ }^{111}$ Ljudska prava: odraz institucionalne nemoći. Godišnji izveštaj: Srbija 2010, [prir.] Helsinški odbor za ljudska prava u Srbiji, Beograd 2011, s. 556. 